\title{
IAMJ
}

INTERNATIONAL

AYURVEDIC

MEDICAL JOURNAL

\section{AN AYURVEDIC MANAGEMENT OF VICHARCHIKA - A CASE REPORT}

\section{$\underline{\text { Chander Shekhar Sharma }}^{1}$, Amrita Sharma $^{2}$}

BAMS, MD (Ayu), NDDY, Professor and Head, Department of Kayachikitsa, Dayanand Ayurvedic College, Jalandhar, Punjab, India

BAMS, MD (Ayu), MBA, NDDY, CFN, DNHM, CYEP, Physician, Lifestyle Counselor, Yoga Physiologist, Spiritual Healer, Punjab, India

Corresponding Author: shekhars76@gmail.com

https://doi.org/10.46607/iamj15p4062020

(Published online: September 2020)

Open Access

(C) International Ayurvedic Medical Journal, India 2020

Article Received:10/09/2020 - Peer Reviewed:18/09/2020 - Accepted for Publication:20/09/2020

Check for updates

\section{ABSTRACT}

Twak has intimate relationship with the Doshas, Sparsnendriyaas a whole is considered as Vatasthana. Twak and Rasadhatu are considered as Bahya Rogmarg. Eczema is widely considered to be specific type of Kushtha known as Vicharchika, with complex pathology, varying presentations, and various treatment modules within the context of Ayurveda. The Kushtha is generally used as a universal term for all kinds of skin disorders, which is further classified in two divisions i.e. Mahakushta and Kshudrakushta and Vicharchika is mentioned under Kshudrakushta. Vicharchika is considered as Rakta Pradoshaja Vikaras. Recurrences and chronic course is a distinct feature for this disease. Eczema is primarily managed with topical steroids, antiseptic, immune-suppressors drugs to inhibit immune and inflammatory response. However, it does not provide treatment for the root causative factors. Ayurveda provides principle-based treatment for eczema by cleansing vitiated Dosha and balancing the Dosha and Dhatus. The case report involved a female patient of Pitta-Kaphaj Prakruti with exudate, intense itching, and erythema of the skin.Within one month of the beginning the treatment, eczematous lesions were improving and even after two months, the patient showed no signs of recurrence.

Keywords: Vicharchika, eczema, Twak Vikar, dermatitis, pruritis 


\section{INTRODUCTION}

The skin accounts for the largest barrier between body and the environment, which protects from various external physical, chemical, biological threats. The skin is much more than just a protective coat and encounters a high number of antigens at the embrasure between the body and the surrounding environment ${ }^{1}$. Skin diseases involve the worldwide population at significant levels but are more prevalent among children and in low socio-economic groups, basically due to poor hygienic practices. There are ample evidences which suggest that skin infections are more prevalent in extreme climatic conditions. Dermatitis offers a wide clinical picture ranging from minor to major forms with erythematous rash ${ }^{2}$. Cardinal features of itchy inflammation of skin (eczema) are redness, eruptive skin lesions, papules which go along with an intense pruritus and cutaneous hyperreactivity ${ }^{3}$. Atopic dermatitis can be distinguished with cracked or scaly skin, discolored patches, red skin, papules, oozing from lesion, and intense itching, which can secondarily cause disturbed and hamper the quality of life. The clinical picture may be a combination of all or presence of individual sign symptom depending upon the phase of the disease. To live with skin disease, have a negative impact on quality of life because of continuous physical agony due to itching, scratching, oozing, and pain in lesions and thereby psychological discomfort.It can lead to high stress levels which also disturb the positive outcome at workplace, affect the lifestyle and also restrict the social activities of patient. Mental depression is also of big concern in dermatological issues as the patient in maximum cases begins to feel desperate, awkward, anguish due to the chronic nature of the disease. The research in dermatology has provided sufficient evidences that mast cells are responsible for immediate allergic reactions / inflammatory disease by releasing mediators stored in them including atopic dermatitis ${ }^{4}$. Mast cells are found all over the body, chiefly near the surface of the skin, blood vessels, and lymphatic vessels. Eczema occur as a result of delayed type hypersensitivity mediated by adaptive immune system which kills infected host cells and activate other immune cells, producing cytokines causing inflammatory response of the skin ${ }^{5}$. The clinical lesions on skin may be acute onset or chronic depending on the severity of response to the antigen ${ }^{6}$.The term eczema is predominantly applied to a range of constant or repeated skin rashes identified by redness, skin swelling, itching and dryness, with possible crusting, peeling off, blebs, fissure, fluid discharge or bleeding at times. Areas of interim skin discoloration occasionally show healed lesions, though scarring is rare ${ }^{7}$. As described in terms of Nidana, Purvarupa, Rupa, Samprapti and Chikitsa, Vicharchika can unquestionably be co-related with the modern explication of eczema. The Sushruta Samhita defines Vicharchika as "excessive pain and itching", the Charak Samhita describe Vicharchika in a slightly different way "It consists of pimples which are pruritic, black in color, and associated with oozing ${ }^{9}$.The paramount features of Vicharchika include Kandu (pruritis), Pidika (popular rash), Shyavata (discoloration), Bahusrava (profuse oozing) ${ }^{10}$, Raji $^{11}$ (marked lining/ lichenification), Ruja (pain), Rukshata (excessive dryness). As per Ayurvedic texts it is a Kapha pradhana tridoshaja vyadhi ${ }^{12}$ which in its progression involves Rasa, Rakta, Mamsa and Kleda (as Dushya) ${ }^{13}$. The fundamental cause of all disease is considered to be Agnimandya ${ }^{14}$. Acharya Charaka has defined Vicharchika as a Kapha condition, which would have Kapha accumulating and aggravating in the AnnavahaSrotas, overflowing in the Rasavaha and RaktavahaSrotas, and relocating in the Mamsavaha Srotas, resulting in swelling, itching and exudate. The types of Kushtha with similar causative factors have different presentation depending upon pain, color, symptoms, effects, name and treatment according to proportional variation, association, and location of Doshas $^{15}$. Acharya Charaka has mentioned that all skin disease is Sannipatika by nature, but presentation may vary according to dominance of specific Dosha. With the combinations of Doshas, non-identical numerous conditions will arise, and therefore treatment protocol should be planned on the prevalence of the Dosha involved. Initially lodgment and exacerbation of Dosha occur in the Rasa Dhatu, which progresses 
to next Rakat Dhatu involving both Rasa and Rakta, it moves on, manifests, and expands in the Rasa, Rakta and Mamsa. The vitiated Rasa manifests differently depending on the Dosha involved viz. dryness for Vatadosha, inflammation and burning for Pittadosha, and swelling and itching associated with Kaphadosha. The pathologic process of Vicharchika is complex which naturally involves more than one Dosha. When Dhatus are intricated simultaneously, it makes the existing condition more complicated. Texts shows various evidences that Raktadusti is counted one of the foremost causes of various dermatological conditions ${ }^{16}$.

Case History: A female patient aged 54 years, housewife by occupation reported in the OPD of MCDAV Ayurvedic hospital, Jalandhar with complaint of patches, itching and redness, over both buttocks and inner side of both thighs since last one year. On enquiry patient told that sometimes it is painful, and itching becomes more intense at night and sometimes clear fluid oozes out. Her appetite, micturition, bowel habits were normal, and sleep was disturbed due to itching and patient told that she used to sleep in daytime. She gave history of some relief in itching after applying local medication. On examination, the lesions were found to be circular, grouped and red in color; crusting present and itching marks were also witnessed. Patient also informed that whenever she takes spicy, oily, sour, salty food items, Masha, Tilla, milk, Gudd, curd, chilies, garlic, after heavy physical exertion and exposure to excess heat and indigestion always makes the symptoms worse. There was no history of any known skin allergy in the patient and also there is no family history of skin disease. There was no history of any kind of other associated systemic illness or any kind of prolonged oral medication. As Kandu, Pidika, Srava, Rukshta, Ruja were present so patient was diagnosed as a case of Vicharchika (dermatitis) and Shaman Chikitsa was planned. All routine haematological reports were within normal limits. On examination patient presented with Figure 1 and Figure 2:

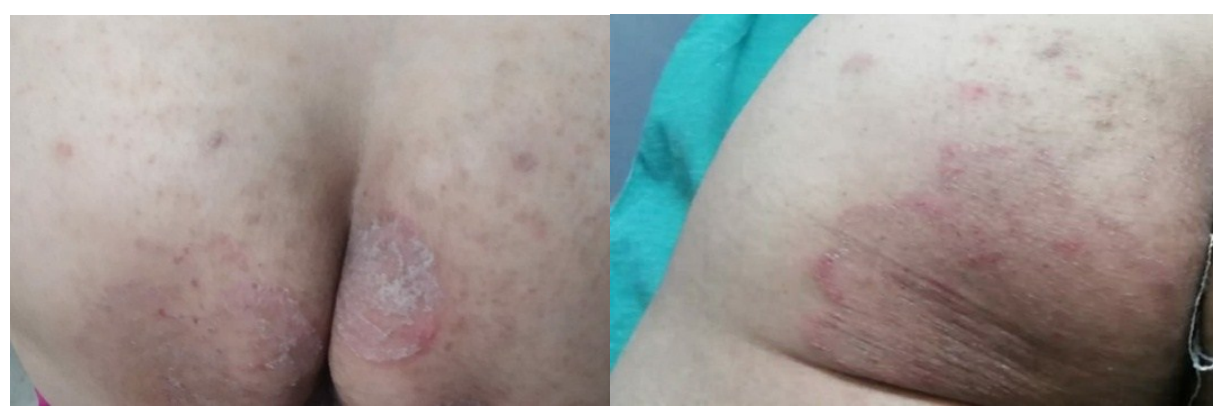

Figure 1

Figure 2

Vital Data:

PR - 80 / min, Regular, BP - 110/80 mmHg, Temperature - Afebrile, Respiratory Rate - 16 / min rhythmical.

Personal history and Ashtavidha Pariksha is mentioned in table1 and table 2 respectively.

Table 1: Personal History

\begin{tabular}{|l|l|l|}
\hline Name: XYZ & Bala: Madhyama & BP: $110 / 80 \mathrm{mmHg}$ \\
\hline Age: 54 years & Sleep: Disturbed due to itching & Weight: $53 \mathrm{~kg}$ \\
\hline Sex: Female & Addiction: None & Height: $148 \mathrm{~cm}$ \\
\hline Marital Status: Married & Bowel Habit: Constipated & \\
\hline Occupation: Housewife & Appetite: Normal & \\
\hline
\end{tabular}


Table 2: Ashtavidha Pariksha

\begin{tabular}{|l|l|}
\hline Nadi: $76 /$ min & Shabda: Clear \\
\hline Mala: Constipation & Sparsa: Normal \\
\hline Mutra: Normal & Drik: Normal \\
\hline Jihva: Saama (coated) & Aakriti: Madhyam \\
\hline
\end{tabular}

\section{Systemic Examination:}

Cardiovascular system - Heart sounds(S1S2) appears to be normal, no adventitious sound was detected.

Respiratory System - Chest appears to be normal in shape, movements of chest wall bilaterally equal. Air entry appears to be adequate bilaterally, no added sounds detected.

GIT System - On examination abdomen appears to be normal is shape, movements of abdominal wall appears to be normal, umbilicus central in position, on palpation abdomen is soft, non-tender and resonant all over. No organ seems to be palpable; bowel sounds appears to be adequate.

Musculoskeletal System - On examination locomotor system appears within normal limits. Deep and superficial reflexes are intact.

Dermatological Examination - Hands, mouth, scalp, nails appears to be normal. Lesions present over gluteal region bilaterally and inner side of thighs ranging from three to four centimeters in size, red in color, crusty in texture, round in shape and distribution is symmetric and grouped.

Nidan: It has been mentioned in the Samhitas that sugarcane, sesame, Ghee, curd and milk, the habit of the sleeping by day, taking sour fruits, etc. all of these excessively aggravate Kapha, Pitta as well as Rakta. A patient with dermal manifestations should avoid taking meat, fat, milk, curd, oil, various eatables prepared from corn flour, sours, incompatible foods and overeating, uncooked foods or that which cause disturbed digestive fire i.e indigestion, foods that cause acidity etc. Also, in the present case study these factors seem to have played major role as etiological factors.

\section{Samprapti Ghatak:}

Dosha:Tridosha (Kapha-Pitta predominant), Agni: Manda, Doshagati: Vriddhi, Tiryak
Vyadhimarga: Bahya; Dushya: Rasa, Rakta; Srotas. Rasavaha, Raktavaha; Srotodushti: Vimarga Gamana; UdbhavaSthana: Aamashaya; VyaktiSthana: Twak; Svabhava: Chirkari

\section{Treatment plan:}

The Shodhan Chikitsa was not possible due to uncooperative behavior of patient, the Shaman Chikitsa was planned and drugs were selected for oral administration for two weeks along with abstinence from Aaharaj, Viharaj and Mansik Nidan:

1 Haridrakhand 4 gm TDS

2 Cap SheerishHaldi 2 cap TDS

3 NimbadiChuran 3 gm TDS

4 GandhakRasayan 1 -tab TDS

5 KaishoreGugglu 2 TDS

6 Mahamarichyadi Tail for local application four times in a day.

\section{Diet and Hygiene:}

The diet was advised, keeping in mind the Dosha predominance to pacify the Dosha that is primarily vitiated. Hot and spicy foods like chilies, raw onions and garlic, fermented foods like pickles, curd and yogurt, excess salt intake, sour fruits, fried foods, ice cream and cold drinks, strong tea, excess intake of nuts were restricted and patient was advised to take easily digestible, nutritious diet like, Ghiya, Torri, Moogdaal, Masardaal, Khichdi, preboiled luke warm water to drink, seasonal fruits etc. Patient was also advised to maintain proper hygiene of the affected area.

\section{Observation and Results:}

On day 1, the patient reported with Kandu, Pidika, Shyavta, Rukshta, Raji, Ruja, Srava. After 7 days patient showed encouraging improvement especially in Ruja, Kandu and patient was able to enjoy the sound sleep at night (which was disturbed previously), at the end of two weeks (14 days) it was observed that patient showed marked improvement in signs and symp- 
toms, as evident from the Figure 3.Other symptomatic observations made are described in table 3.

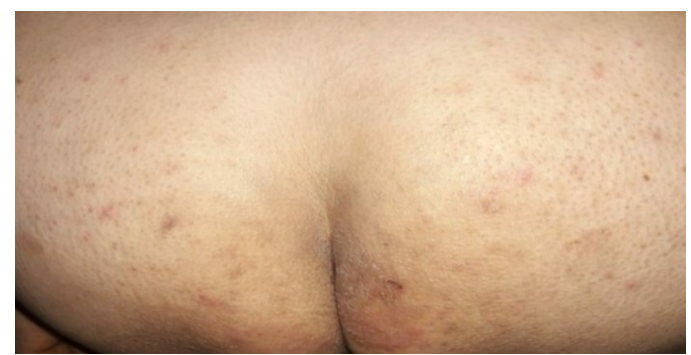

\section{Figure 3}

Table 3

\begin{tabular}{|l|l|l|l|l|}
\hline S.NO & Assessment Parameters & Day 1 & Day 7 & Day 14 \\
\hline 1 & Kandu (Pruritis) & Grade 3 & Grade 2 & Grade 0 \\
\hline 2 & Pidika (Papular rash) & Moderate & Mild & Absent \\
\hline 3 & Shyavata (Discoloration) & Apparent & Absent & Absent \\
\hline 4 & Bahusrava (Profuse oozing) & Moderate & Mild & Absent \\
\hline 5 & Raji (Marked lining/Lichenification & Mild & Mild & Absent \\
\hline 6 & Ruja (Pain) & Grade 1 & Grade 0 & Grade 0 \\
\hline 7 & Rukshta (Excessive Dryness) & Apparent & Mild & Absent \\
\hline
\end{tabular}

\section{Grades of severity of itching:}

Grade 0 - No itching

Grade 2 - Moderate itching (Kandu)

Grade 1 - Mild itching (Ishatkandu),

Grade 3- Excessive itching (Bahukandu)

\section{Grades of Pain (Ruja):}

\begin{tabular}{|l|l|l|}
\hline Grade 0 - No Ruja & Grade 1-Alpa / Mandaruja & Grade 2 - Ruja with moderate intensity \\
\hline Grade 3 - Tivra Ruja (intense pain) & Grade 4-TivraRuja with Sparshasahatav &
\end{tabular}

\section{DISCUSSION}

Majority of skin disorders are explained under the umbrella of Kushtha Rog, which is considered as a Tridoshaj Vyadhi and has manifestations in the Bahyamarg i.e. Twak. Acharya Sushruta describes formation of Twak from Sukra and Shonit whereas in Shashilekha commentary by Indu has stated that Twak is formed from Saarabhag of Raktadhatu .Etiological factors which are responsible for manifestation, transmission and progression of the disease include Virudhaahar, Mithyaahar, Ajirnahar, Ahitashan leads to Tridoshdushti, Snigdh Anpaan, Guru Anpaan, Snehati Sevan causes Kapha Prakopa and Attiamal, Atilavan food items cause vitiation of Pitta Dosha, Kledvridhi and Rakata-Mamsadushti. Vitiated Doshas cause manifestation of Twak Roga by involving Dhatus especially Rasa Dhatu and Mamsa Dhatu and availability of disease suitable etiological factor leads to further establishment and progression of the disease. Keeping in view all these factors, drug formulations for Shaman Chikitsa were chosen that helped in Samprapati Vighatan in this case. The formulation Haridrakhand is widely accepted for Twak Roga and act as anti-allergic, anti-inflammatory, antioxidant, antihistamine as well as an antipruritic and also act as Kapha-Pitta Shamak resulting into marked improvement is this case. In cap Sheerish Haldi, Sheerish has been mentioned as Vishghan, Vednasthapak and its Madhur, Tikat, Kashaya Rasa helps in reducing Srava, Dah, Kandu, Pidika etc. It has got mast cell stabilizing property, anti-allergic, anti-fungal, antiinflammatory, anti-microbial properties. Haridra with Tikat, Katu Rasa, Katu Vipak is considered as Kushthaghan, Kandughan. It is a best antiseptic anti- 
inflammatory; antimicrobial, and antioxidant properties, turmeric is an effective treatment for a variety of skin conditions. Nimbadichuran is Tridoshahara, especially Kaphapittahara, Raktadushtihara, Lekhana, Srothoshodana and Deepana, Pachana. Gandhak Rasayan is a purified Sulphur based medicine that has a great antibacterial, antipruritic and antimicrobial properties and works well in itching, burning due to underlying pathology or excess Pitta. Kaishore Gug$g l u$ has anti-allergic, anti- bacterial and blood purifying properties, ingredients are having Katu, Tikat, Kashaya properties which pacifies vitiated Pitta and Kapha Dosha in this case of Vicharchika. It removes excessive Pitta from the body and thus helps in providing soothing effect to the skin. It helps in removing impurities from the blood thus help in treating skin diseases arising due to Rakat Dosha vitiation. Mahamarichyadi Taila is a formulation with many ingredients which contains antifungal and antiseptic properties. The application of oil increases liquid content and leads to Utkleshan (removal of vitiated Doshas). It enters in the cells easily as cell membrane is made up of phospholipids and acts as solvent for various metabolic waste products. Besides these properties, Vranshodhak and Vranropak properties also contributed a lot in this case of Vicharchika. In view of chronic and recurring nature of Vicharchika, the strengthening of the psychological component of individuals is to be specifically taken care of alongwith medications and maintaining hygiene. In all respects, if this condition is ignored, it becomes more difficult to manage. We can manage to cut a young tree with a little effort but more advanced efforts may be required to cut a fully grown tree, so early diagnoses and proper management of disease increases cure chances. Skin should be explored in terms of mental, physical health and on the basis of status of Rasa and Rakat Dhatu (as physical and functional state of which if reflected through the Twak).In the present case study marked improvement has been successfully achieved. It gives us clue to cure skin diseases with appropriate selection of various formulations.

\section{CONCLUSION}

The skin is the boundary between the outside world and us, its appearance and health status have a vital role as far as cosmetic perspective is concerned. It is also a direct representation of the health, or disease, within us. When we are healthy, mentally and physically, our skin glows, and conversely without that health, our skin lacks luster and shows our imbalance. Vicharchika, a complex disease, greatly affects the quality of life of the sufferer. On the basis of the outcome of this case study, it may be concluded that ayurvedic formulation with proper selection of drugs can increase the cure percentage and help the patients of dermatology to live the life with dignity.

\section{REFERENCES}

1. Bos JD, Zonneveld I, Das PK, Krieg SR, van der Loos CM, Kapsenberg ML. The skin immune system (SIS): distribution and immunopheno type of lymphocyte subpopulations in normal human skin. J Invest Dermatol 1987; 88(5):569-573.

2. Leung DY, Bieber T. Atopic dermatitis. Lancet 2003; 361(9352):151-160.

3. Kay AB. Allergy and allergic diseases. Second of two parts. N Engl J Med 2001; 344(2):109-113

4. Theoharis C. Theoharides, Konstantino- DionysiosAlysandroatos, et al. "Mast Cells and Inflammation," Elsevier; Biochimica et Biophysica Acta-Molecula Basis of Disease,.1822(1) (January!2012):24

5. Sehgal NV. Eczema. In: Textbook of clinical dermatology, 4th ed. New Delhi: Jaypee Brothers medical publishers (P) Ltd: 2004.p.19.

6. Kasper: Harrison's Principles of Internal Medicine, McGraw Hill Medical Publishing Division, NewDelhi, 16th edition 2004, p.289.

7. hhtp://pagead2. googlesyndication.com/pagead/ads?client=Ca-pub3339185, H:|plants $\backslash$ Eczema-Article.html.

8. Sushrutsamhita Nidansthan, Hindi commentary by Kaviraj Ambikadatta Shastri, Chaukhambha publication Varansi, reprint in 2012, chapter59, page 322

9. Charaksamhita chikitsasthan hindi commentary by Pandit kashinath shastri Chaukhambha publicationvaranasi reprint 2011:7/26 page 252

10. Agnivesha, Charaka Samhita, revised by Charaka \& Dridhabala with Ayurveda Deepika commentary of Chakrapani datta, edited by Vd. Yadavaji Trikamji 
Acharya, Chaukhambha Prakashan, Varanasi, reprint 2007; Chikitsa Sthana 7/26., Pg.451.

11. Sushruta, Sushruta Samhita with Nibandha Sangraha commentary of Dalhana and Nyaya Chandrika Panjika of Gayadasa on Nidanasthana edited by Vd. Yadavji Trikamji Acharya \& Narayan Ram Acharya, Chaukhambha Orientalia, Varanasi, reprint 2007, Nidana Sthana 5/13, Pg.285.

12. Agnivesha, Charaka Samhita, revised by Charaka \& Dridhabala with Ayurveda Deepika commentary of Chakrapanidatta, edited by Vd. Yadavaji Trikamji Acharya, Chaukhambha Prakashan, Varanasi, reprint 2007; ChikitsaSthana 7/10, 30, Pg.450 \& 451.

13. Agnivesha, Charaka Samhita, revised by Charaka \& Dridhabala with Ayurveda Deepika commentary of Chakrapanidatta, edited by Vd. Yadavaji Trikamji Acharya, Chaukhambha Prakashan, Varanasi, reprint 2007; Chikitsa Sthana 7/9, Pg.450.

14. Vagbhatta, Ashtang Hridaya with Sarvangasundari commentary of Arunadatta \& Ayurveda Rasayana of Hemadri, edited by Pt. Hari Sadashiva Shashtri, Chaukhambha Surbharati Prakashan, Varanasi, reprint2007; Nidana Sthana 12/1, Pg.513

15. Charaka Samhita Handbook on Ayurveda, Ed.Gabriel Van Loon, Vol.2 (2003): 972, (Ch. Chi. 5/4).

16. Hiren N. Raval and A.B. Thakar, "Role of Raktamokshana by Jalaukavacharana and Siravedhana in the Management of Vicharchika (Eczema),"Ayu, 33(1) (January-March 2012):68.

\section{Source of Support: Nil \\ Conflict of Interest: None Declared}

How to cite this URL: Chander Shekhar Sharma \& Amrita Sharma: An Ayurvedic Management of Vicharchika - A Case Report. International Ayurvedic Medical Journal \{online\} 2020 \{cited September, 2020\} Available from: http://www.iamj.in/posts/images/upload/2536_2542.pdf 